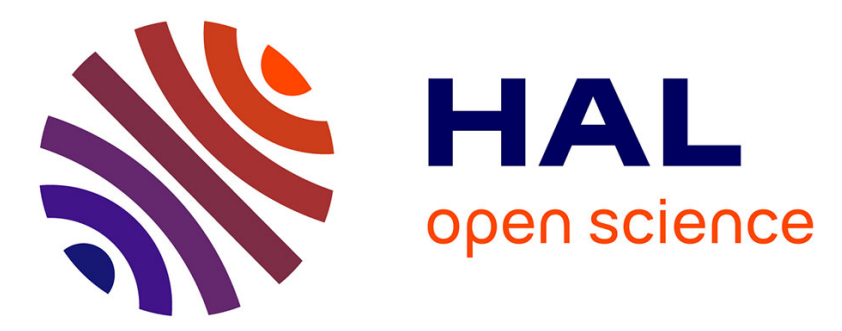

\title{
MASSIVE HILLOCK GROWTH ON CATHODE SIDE OF TEST STRUCTURE DURING ELECTROMIGRATION EXPERIMENTS
}

\author{
B. Bacconnier, G. Lormand, F. Martin
}

\section{- To cite this version:}

B. Bacconnier, G. Lormand, F. Martin. MASSIVE HILLOCK GROWTH ON CATHODE SIDE OF TEST STRUCTURE DURING ELECTROMIGRATION EXPERIMENTS. Journal de Physique Colloques, 1988, 49 (C4), pp.C4-307-C4-310. 10.1051/jphyscol:1988464 . jpa-00227962

\section{HAL Id: jpa-00227962 https://hal.science/jpa-00227962}

Submitted on 1 Jan 1988

HAL is a multi-disciplinary open access archive for the deposit and dissemination of scientific research documents, whether they are published or not. The documents may come from teaching and research institutions in France or abroad, or from public or private research centers.
L'archive ouverte pluridisciplinaire HAL, est destinée au dépôt et à la diffusion de documents scientifiques de niveau recherche, publiés ou non, émanant des établissements d'enseignement et de recherche français ou étrangers, des laboratoires publics ou privés. 


\title{
MASSIVE HILLOCK GROWTH ON CATHODE SIDE OF TEST STRUCTURE DURING ELECTROMIGRATION EXPERIMENTS
}

\author{
B. BACCONNIER, G. LORMAND* and F. MARTIN \\ D. LETI/IRDI, CEA, CEN/G, 85x, F-38041 Grenoble Cedex, France \\ * Laboratoire d'Etude des Matériaux, Bât. 303, INSA, \\ F-69621 Villeurbanne Cedex, France
}

\begin{abstract}
Résumé - Nous observons l'apparition d'excroissances sur la cathode des structures de test an cours d'essais d'électromigration. Ce phénomène est opposé à celui habituellement observé en présence de gradients thermiques élevés aux extrémités des lignes de test. Sur les films Al-Si-Ti déposés à $80^{\circ} \mathrm{C}$, l'apparition des excroissances est accompagnée de celles de fortes dépressions du coté de l'anode. En l'absence d'un réseau continu de joints de grains, la quantité de matière traversant entièrement la ligne est négligeable. Il en résulte une divergence importante du flux de matière aux deux extrémités de cette ligne. Sur les films Al-Cu, l'apparition des excroissances et le déplacement de leur front vers l'anode est controlê par l'électromigration progressive du cuivre. La divergence du flux de matière est due, comme dans l'expérience des bandes en croix, à une différence entre les coefficients de diffusion intergranulaire des zones riches et pauvres en cuivre.
\end{abstract}

Abstract - We observed a massive hillock growth on the cathode side of test structures during electromigration experiments. This phenomenon is opposite to the one observed when high self heating thermal gradients are presents. On Al-Si-Ti films, a mass depletion occurs on the anode while hillocks grow on the cathode. The discontinuity of the grain boundary network is responsible for these effects, which are correlated to an enhanced lifetime. On Al-Cu films, hillocks appear at the negative pad - end contact segment junction and their front progagates towards the anode with a velocity proportionnal to current density. As in the cross stripe experiment, the phenomenon results from the difference between the grain boundaries diffusion coefficients in $\mathrm{Cu}$ depleted and $\mathrm{Cu}$ rich areas.

\section{1 - INTRODUCTION}

During electromigration experiments on thin $\mathrm{Al}$ films, a mass flow oriented towards the anode goes through test structures. Mass is primarily transported by grain boundary diffusion $/ 1,2 /$ and mass flow presents local divergences at grain boundary triple points. However, more generalized flux divergences can be induced by differences in grain sizes or self heating thermal gradients. The latter effect leads to mass accumulation on the anode and mass depletion on the cathode, which has provided in the past an extensively used technique for measuring mass flow. Table I presents some of the experiments published on this technique. Not withstanding the fact that mass accumulation or depletion occurs in a quite heterogeneous way (hillocks or voids formation), the microstructure is assumed to be homogeneous in regard to stripe dimensions. This hypothesis does not seem to be questionnable when grain size is much smaller that line width.

We observed a massive hillock growth on the cathode side of test structure during the test of Al-Si-Ti and Al-Cu metallizations. We explain how this particular behavior is related to microstructural inhomogeneities.

TABLE I. Observation of mass accumulation or depletion.

\begin{tabular}{|c|c|c|c|c|c|c|}
\hline Metal & Method & $\begin{array}{c}\text { Line width } \\
(\mu \mathrm{m})\end{array}$ & $\begin{array}{l}\text { Grain size } \\
(\mu \mathrm{m})\end{array}$ & $\begin{array}{c}\text { Accumulation } \\
\text { Side }\end{array}$ & $\begin{array}{l}\text { Depletion } \\
\text { Side }\end{array}$ & Reference \\
\hline Al & T.E.M. & 25 & $0.5-5$ & anode & cathode & $\mathbf{1}$ \\
\hline AI & Electron beam & 45 & 1 & anode & cathode & 3 \\
\hline$A 1-C u-C r$ & S.E.M. & 7 & 1800 & anode & cathode & 4 \\
\hline Al-Mg & E.P.M.A. & 7 & $\cdots$ & anode & cathode & 5 \\
\hline AI & S.E.M. & 4 & 6 & anode & cathode & 6 \\
\hline Al-Si-Ti & S.E.M. & 1.4 & 1 & cathode & anode & present work \\
\hline $\mathrm{Al}-\mathrm{Cu}$ & S.E.M. & 4 & 1.5 & cathode & anode & present work \\
\hline
\end{tabular}




\section{2 - EXPERIMENTS}

$\mathrm{Al}-\mathrm{Si}-\mathrm{Ti}(1 \mathrm{wt} . \% \mathrm{Si}-1.8 \mathrm{wt} . \% \mathrm{Ti})$ and $\mathrm{Al}-\mathrm{Cu}(0.5 \mathrm{wt} \% \mathrm{Cu})$ films were sputtered on respectively Ti-W and Ti-N diffusion barriers both on $1000 \AA$ of thermally grown SiO2. Film thickness was $0.6 \mu \mathrm{m}$ for Al-Si-Ti and $0.7 \mu \mathrm{m}$ for Al-Cu films. Al-Cu films were deposited with $100 \mathrm{~V}$ bias voltage. Table II presents elaboration and electromigration test conditions. Failure criterion was an increase of $10 \%$ of the electrical resistance. Al-Si-Ti films deposited at 80 and $200^{\circ} \mathrm{C}$ were studied in T.E.M.. Cu profile on both tested and untested Al-Cu lines was measured by electron probe micro-analysis (E.P.M.A.). All lines were observed in S.E.M. after testing.

TABLE I I. Elaboration and electromigration test conditions .

\begin{tabular}{|c|c|c|c|c|c|}
\hline Metal & $\begin{array}{c}\text { Deposition } \\
\text { temperature }\left({ }^{\circ} \mathrm{C}\right)\end{array}$ & $\begin{array}{c}\text { Annealed } \\
30 \mathrm{mn}\left(450^{\circ} \mathrm{C}\right)\end{array}$ & $\begin{array}{l}\text { Line width } \\
(\mu \mathrm{m})\end{array}$ & $\begin{array}{c}\text { Current density } \\
(\mathrm{GA} / \mathrm{m} 2)\end{array}$ & $\begin{array}{l}\text { Temperature } \\
\left({ }^{\circ} \mathrm{C}\right)\end{array}$ \\
\hline Al -Si - Ti & 80 & yes & $1.4,4$ & 15 & 200,170 \\
\hline$\overline{\mathbf{A l}-\mathbf{S i}-\mathbf{T i}}$ & $120,160,200$ & yes & $1.4,4$ & 15 & 200 \\
\hline $\mathrm{Al}-\mathrm{Cu}$ & Room Temp & yes & 4 & 10 & 200 \\
\hline $\mathrm{Al-Cu}$ & Room Temp & no & 4 & 10 & 200 \\
\hline
\end{tabular}

\section{3 - RESULTS}

We observe hillock growth and mass depletion respectively on the cathode and on the anode of Al-Si-Ti $1.4 \mu \mathrm{m}$ lines deposited at $80^{\circ} \mathrm{C}$ (Fig. 1). When the deposition temperature increases, both effects disappear and the lifetime of 1.4 $\mu \mathrm{m}$ lines decreases while that of $4 \mu \mathrm{m}$ lines increases (Fig. 2). Grain size is ranging from 0.5 to $1.5 \mu \mathrm{m}$ both for $80^{\circ} \mathrm{C}$ and $200^{\circ} \mathrm{C}$ deposited films. Grain boudaries of $80^{\circ} \mathrm{C}$ deposited films look more like cell walls than like well defined grain boundaries. Mass depletions observed on the anode have lateral dimensions of about the grain size. We have noted that hillock growth can occur far from the end-contact segment and test line junction (farther than $0.1 \mathrm{~mm}$ ) and is more heterogeneous that anode depletion. Hillocks volume, evaluated by S.E.M. observations, corresponds to a mass flow of $0.35 \mu \mathrm{m} 3 / \mathrm{s}$ for $200^{\circ} \mathrm{C}$ and $0.15 \mu \mathrm{m} 3 / \mathrm{s}$ for $170^{\circ} \mathrm{C}$ testing.

The behaviors of annealed or unannealed Al-Cu films are roughly the same : hillocks first appear at the negative pad and end-contact segment junction (Fig. 3) then hillock front propagates towards the anode with a velocity proportionnal to current density (Fig. 4). We detect no change in conductor shape on the anode. Cu profiles indicate a Cu depletion in the areas where hillocks are present. Figure 5 show the typical variations of electrical resistance of unannealed lines during test. We notice, after a an exponential type decrease in the first hours, a steep decrease of resistance occuring approximatively at the same time for all films. Failure occurs randomly during this decrease.

\section{4 - DISCUSSION}

Effects induced by electromigration can occur when mass flow divergence is not equal to zero everywhere in the conductor. However, it often seems necessary to define mass flux in a given section of the test structure in order to calculate diffusion coefficients from the observed effects $/ 1$. This flux can be expressed as the sum of the fluxes in each grain boundary of the considered section and assuming in first approximation that grain boundaries are the same may be written :

$$
\mathrm{J}=\mathrm{Z}^{*} \text {.e.p.j / (kT).8.D0.exp(-Q/kT).n.l }
$$

where $J$ is the mass flux, $Z^{*}$.e the effective charge, $\rho$ the resistivity at the temperature $T, j$ the current density, $n$ the number of grain boundaries crossing the section, $\delta$ the grain boundary width, $t$ the film thickness, D0 and $Q$ define the grain boundary diffusion coefficient $\mathrm{D}$, and $\mathrm{k}$ and $\mathrm{T}$ have their usual meaning. We are going to see now how variations of $\mathbf{n}$ and $\mathrm{D}$ on our test structures allow to explain the observed effects.

Al-Si-Ti films deposited at $80^{\circ} \mathrm{C}$ have a grain size close to the width of $1.4 \mu \mathrm{m}$ lines. Hence, there is always a discontinuity of the grain boundary network on the test-line not far from the end-contact segments, which means locally $\mathrm{n}=0$. In this place, mass flux divergence is strictly proportionnal to mass flux, and leads to strong accumulations or depletions. Mean time to failure of these lines has been found higher than that of larger lines. This result can not be explained simply by a grain size dependence of electromigration resistance as reported for others materials $/ 7,8 /:$ when deposition temperature increases, $4 \mu \mathrm{m}$ lines have a larger lifetime than $1.4 \mu \mathrm{m}$ lines, the contrary being obtained on 
$80^{\circ} \mathrm{C}$ deposited lines with the same grain size. The cell wall aspect of grain boundaries in the $80^{\circ} \mathrm{C}$ deposited films may explain a more homogeneous diffusion coefficient than well defined grain boundaries and thus divergences at triple points of these structures are less important. The shorter current stress duration (lifetime being shorter) associated with the high temperature deposited films is certainly the reason why we do not see any hillocks on the cathode of these films. The variation of the extruded volume with temperature gives an activation energy of $0.5 \mathrm{eV}( \pm 0.2 \mathrm{eV})$ between $170^{\circ} \mathrm{C}$ and $200^{\circ} \mathrm{C}$. Eq. 1 applied to the end contact segment gives a value of $1 \mathrm{E}-16 \mathrm{~cm} 3 / \mathrm{s}$ for $\mathrm{dD}$ at $200^{\circ} \mathrm{C}$, which is close to the value of pure aluminium $/ 5 /$. The fact that hillocks can grow far from the flux divergence section would require further considerations on stresses and defects concentration to be discussed.

It would be interesting to enlighten the reasons why such a hillock growth has not been reported for others alloys. A competition between thermal gradients and microstructure effects is an hypothesis, because our test structures tend to lower the thermal gradients more than structures in which line is in direct contact with pad. This hypothesis becomes questionnable when grain size is much lower than pad size (see Table $I, / 6 /$ ) because even if thermal gradients are high, bulk diffusion is always much smaller than grain boundary diffusion at usual test temperatures. However, the case of passivation cracking localized on the cathode of test structure during electromigration tests on layered structures has been reported $/ 9 /$. This unexplained behavior was related to an increase of lifetime.

The apparition of hillocks on the cathode side of test structure is related to $\mathrm{Cu}$ depletion. According to the numerous studies of $\mathrm{Cu}$ influence on $\mathrm{Al}$ grain boundary diffusivity $/ 10,11,12 /$, we may state that grain boundaries of $\mathrm{Cu}$ depleted areas present a much higher diffusion coefficient than those of non affected areas. Hence a higher mass flow, in the depleted areas and a mass accumulation (hillock growth) arises at the edge of the depleted area. This explanation has already been given by Ho and Howard /11/ to account for the simultaneous apparition of hillocks and voids during the cross stripe experiment. When the edge of depletion area travels along the test line, an additionnal aluminium volume is pushed into the line, leading to the observed steep decrease of electrical resistance. It is difficult to determine quantitavely whether hillocks keep growing or not after areas have been completely depleted. However, the size of hillocks is relatively constant on the end contact segment. Futhermore, the steep decrease of resistance ends when hillocks have invaded the whole test line before failure. Threfore we conclude that hillock growth results mainly from the difference in diffusion coefficients.

\section{ACKNOWLEDGMENTS}

The authors would like to thank A. M. Papon for T.E.M. observations, A. Ermollieff et S. Marthon for E.P.M.A. measurements, M. Papapietro, J. P. Joly and C. Arena for encouraging discussions.

\section{REFERENCES}

/1/ I. A. Blech and E.S. Meieran, "Electromigration in thin Al films", J. Appl. Phys. 40 (1969) 487.

12/ R. Rosenberg and L. Berenbaum, "Resistance monitoring and effects of nonadhesion during electromigration in aluminium films", Appl. Phys. Lett. 12 (1968) 201.

13/ J.Weise, "Quantitative measurements of the mass distribution in thin films during electromigration experiments", Thin Solid Films 13 (1972) 169.

14/ A. Gangulee and F.M. d'Heurle, "Anomalous large grains in alloyed aluminium thin films. II. Electromigration and diffusion in thin films with very large grains", Thin Solid Films 16 (1973) 227.

15/ A. Gangulee and F.M. d'Heurle, "Mass transport during electromigration in Aluminium-Magnesium Thin films", Thin Solid Films 25 (1975) 317

16/ J. M. Pierce and M. E. Thomas, "Electromigration in aluminium conductors which are chains of single crystals", Appl. Phys. Lett. 39 (1981) 165.

I7/ S. Vaidya, T. T. Sheng, and A. K. Sinha, "Linewidth dependence of electromigration in evaporated Al-0.5\%Cu", Appl. Phys. Lett. 36 (1980) 464.

/8/ H. U. Schreiber, "Electromigration mechanisms in aluminium lines", Solid-St. Electron. 28 (1985) 1153.

/9/ R. E. Jones, Jr. and L. D. Smith, "Contact spiking and electromigration passivation cracking observed for titanium layered aluminium metallization" , Proceedings VLSI Multilevel Interconnections Conf. (1985) 194.

/10/ P. S. Ho and J. K. Howard, "Nonlinear propagation of void front during electromigration in alloy films", Appl. Phys. Lett. 27 (1971) 261.

/11/ P. S. Ho and J. K. Howard, "Grain-boundary solute electromigration in polycrystalline films", J. Appl. Phys. 45 (1974) 3229.

/12/ F. M. d'Heurle, N. G. Ainslie, A. Gangulee, M. C. Shine, "Activation energy for electromigration failure in Aluminium films containing Copper", J. Vac. Sci. Technol. 2 (1971) 289. 

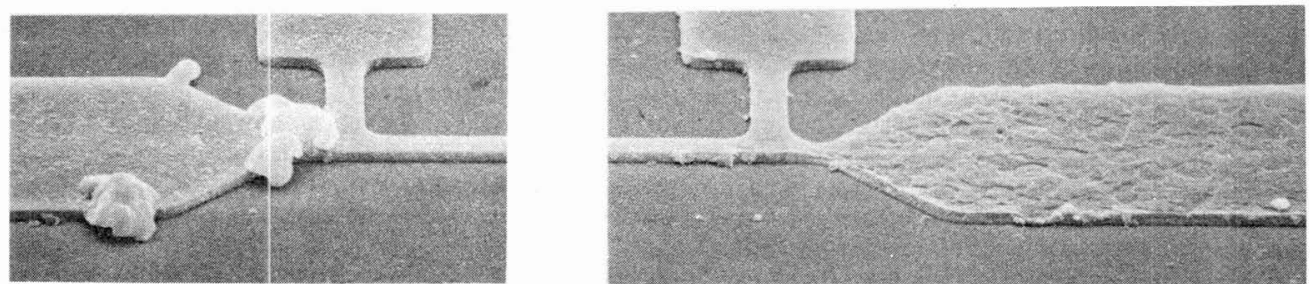

Fig. 1. S.E.M. micrograph of a typical $80^{\circ} \mathrm{C}$ deposited Al-Si-Ti $(w=1.4 \mu \mathrm{m})$ tested structure $\left(\mathrm{J}=15 \mathrm{GA} / \mathrm{m} 2, \mathrm{~T}=200^{\circ} \mathrm{C}\right.$, $\mathrm{t}=200 \mathrm{~h}$ ) : mass accumulation occured on the cathode and mass depletion occured on the cathode. Line lenght is $300 \mu \mathrm{m}$.

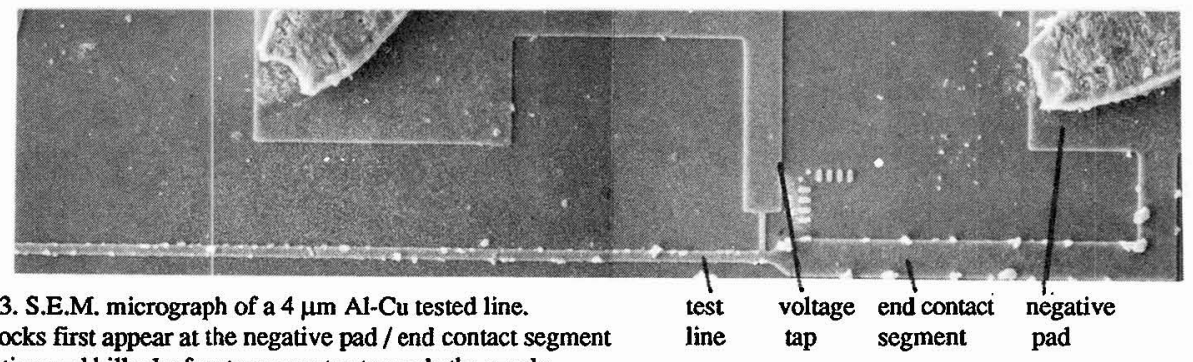

Hillocks first appear at the negative pad / end contact segment junction and hillocks front propagates towards the anode.

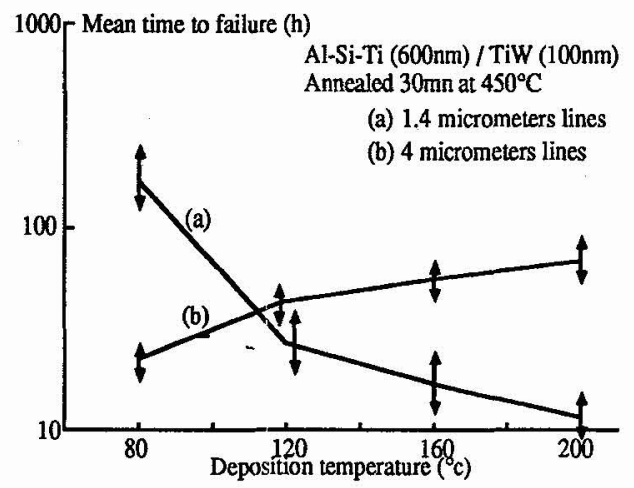

Fig. 2. M.T.F. of Al-Si-Ti 1.4 and $4 \mu \mathrm{m}$ lines versus deposition temperature. Failure criterion is an increase of $10 \%$ of the electrical resistance.

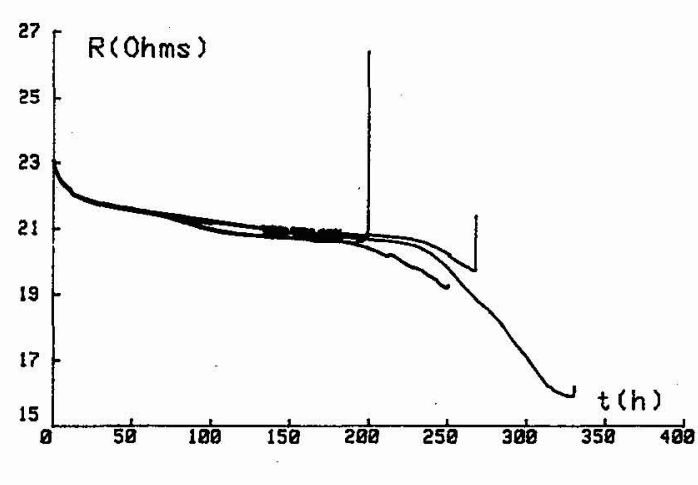

Fig. 5. Typical variation of unannealed Al-Cu lines resistance during test $\left(\mathrm{w}=4 \mu \mathrm{m}, \mathrm{J}=10 \mathrm{GA} / \mathrm{m} 2, \mathrm{~T}=200^{\circ} \mathrm{C}\right)$

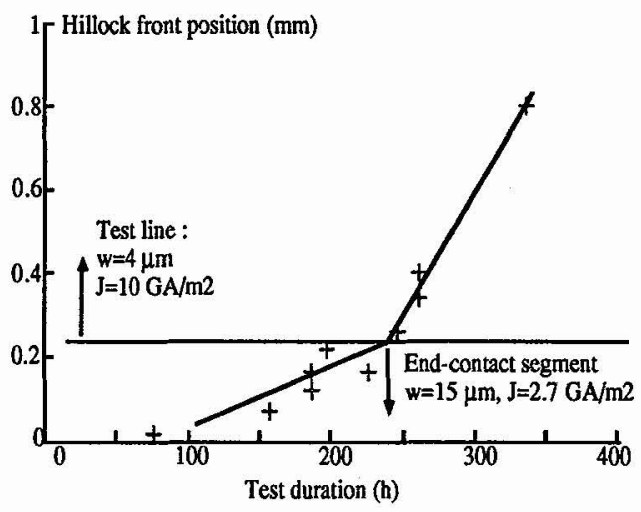

Fig. 4. Hillock front position versus test duration for unannealed $\mathrm{Al}-\mathrm{Cu}$ lines. Slope is proportionnal to current density. 